Vol. 8, No. 2, Oktober 2020, Hal 215-222

ISSN 2302-6405(print) dan ISSN 2714-9765(online)

\title{
PENGEMBANGAN MEDIA INTERAKTIF BERBASIS KEARIFAN LOKAL SEBAGAI MATERI MENYIMAK CERITA RAKYAT
}

\author{
Wiendi Wiranty ${ }^{1}$, Melia ${ }^{2}$ \\ IKIP PGRI Pontianak \\ Email :wiendiwiranty@ikippgriptk.ac.id. ${ }^{1}$, Melia@ikippgriptk.ac.id ${ }^{2}$
}

\begin{abstract}
Abstrak:Penelitian dilakukan bertujuanuntuk melakukan pengembangan media pembelajaran interaktif berbasis kearifan lokal serta dampaknya terhadap aktivitas belajar dan peningkatan hasil belajar siswa pada materi menyimak cerita rakyat. Hasil penelitian ini diharapkan dapat menghasilkan produk berupa media pembelajaran yang sesuai dengan karakteristik materi dan siswa serta meningkatkan aktivitas dan hasil belajar siswa. Metode penelitian ini adalah metode Research and Development dengan desain pengembangan menggunakan rancangan hannafin and Peck. Sesuai dengan tujuan penelitian yang telah dikemukakan, maka sumber data yang digunakan dalam penelitian ini diperoleh dari angket validasi kelayakan media, serta observasi aktivitas belajar dan tes hasil belajar siswa. Subjek penelitian dalam penelitian ini adalah siswa kelas XI SMAN 1 Segedong. Adapun yang menjadi variabel bebas dalam penelitian ini adalah media interaktif berbasis kearifan lokal, sedangkan aktivitas dan hasil belajar sebagai variabel terikat dalam penelitian ini.Teknik pengumpulan data yang digunakan dalam penelitian ini adalah teknik komunikasi tidak langsung, teknik observasi dan teknik pengukuran. Instrument yang digunakan dalam pengumpulan data adalah angket validasi kelayakan, lembar observasi dan tes hasil belajar siswa dengan soal pilihan ganda. Hasil penelitian diperoleh meningkatnya rata-rata hasil belajar siswa dari tes awal sebesar 68,16 menjadi 80,31 pada tesakhir. Kemudian berdasarkan pengujian menggunakan effect size diperoleh nilai 0,86 dengan criteria besar. Hal ini dapat disimpulkan bahwa media interaktif berbasis kearifan local berpengaruh besar terhadap peningkatan hasil belajar siswa.
\end{abstract}

Kata Kunci: media interaktif, hasilbelajar, kearifanlokal.

\section{DEVELOPING AN INTERACTIVE MEDIA BASED ON LOCAL WISDOM AS LISTENING MATERIAL OF FOLKTALES}

\begin{abstract}
The research was conducted to develop interactive learning media based on local wisdom and its impact on improving student learning outcomes in listening to folk tales. The results of this study are expected to produce products in the form of learning media that are in accordance with the characteristics of the material and students and improve student learning outcomes. This research method is the Research and Development method with a development design using the hannafin and peck design. In accordance with the research objectives that have been stated, the data sources used in this study were obtained from the media feasibility validation questionnaire, student learning outcomes tests before and after the use of the media. The research subjects in this study were students of class XI SMAN 1 Segedong. As for the independent variable in this study is interactive media based on local wisdom, while learning outcomes as the dependent variable in this study. The data collection techniques used in this research are indirect communication techniques and measurement techniques. The instruments used in data collection were a validation validation questionnaire and a test of student learning outcomes with multiple choice questions. The results showed that the average student learning outcomes from the initial
\end{abstract}

BASASTRA Jurnal Bahasa, Sastra,dan Pengajarannya

Volume 8 Nomor 2, Oktober 2020, P-ISSN 2302-6405, E-ISSN 2714-9765 
test increased by 68.16 to 80.31 in the final test. Then based on testing using the effect size, the value was 0.86 with large criteria. It can be concluded that interactive media based on local wisdom has a major effect on improving student learning outcomes.

Keywords: interactive media, learning outcomes, local wisdom.

\section{PENDAHULUAN}

Guru harus terampil dan mampu melatih, membina, dan meningkatkan motivasi siswa dalam menyimak, menyediakan sarana penunjang proses belajar mengajar, dan dalam menggunakan media pembelajaran. Kemampuan menyimak diperlukan kesiapan, kesiapan baik dari guru maupun dari siswa itu sendiri dalam pelaksanaan pembelajaran. Dalam hal ini pula guru harus mampu memberikan pembelajaran dengan metode yang dapat membangkitkan aktivitas belajar siswa. Menyimak merupakan keterampilan yang diberikan pada tingkatan sekolah, seperti menyimak berita, wawancara, laporan perjalanan, pidato serta dialog yang terangkum dalam sebuah aktivitas belajar (Hijriyah, 2016). Aktivitas belajar adalah suatu rangkaian kegiatan atau aktivitas secara sadar yang dilakukan seseorang yang mengakibatkan perubahan dalam diri siswa (Ekawati, 2016). Bahwa belajar itu sendiri adalah aktivitas, ativitas mental dan emosional (Sardiman, 20006). Peristiwa belajar didalamnya selalu mengandung aktivitas walaupun kadarnya berbeda-beda (Musrifoh, 2010). Bagaimana seorang guru dapat mengaktifkan siswa belajar tergantung pada kepiawaian guru itu sendiri dalam melaksanakan dan mengelola pembelajaran. Kadar aktivitas yang tinggi dalam belajar membuat siswa memperoleh hasil belajar lebih bermakna. Hasil belajar yang dimaksud dalam penelitian ini adalah angka yang diperoleh siswa yang telah berhasilkan menuntaskan konsepkonsep mata pelajaran sesuai dengan kriteria ketuntasan minimal (KKM) yang ditetapkan sesuai dengan kurikulum yang berlaku. Hal ini berarti siswa harus mencapai nilai yang memuaskan untuk mencapai KKM yang telah ditentukan.

Sesuai dengan kaidah penyusunan rancangan pembelajaran pada kurikulum 2013 (K-13) dimana penguatan proses pembelajaran pada setiap mata pelajaran wajib memasukkan unsur pendekatan saintifik (Sciencetific Approach) (Prihadi, 2014), maka dalam pembelajaran Bahasa Indonesia pada materi menyimak cerita rakyat dapat menggunakan cerita rakyat yang merupakan kearifan lokal daerah setempat dalam pembelajarannya (Komariah, 2018), metode ini diharapkan dapat menumbuhkan rasa semangat siswa untuk belajar sehingga keaktifan dari aktivitas belajar siswa dapat meningkat, secara umum

BASASTRA Jurnal Bahasa, Sastra,dan Pengajarannya

Volume 8 Nomor 2, Oktober 2020, P-ISSN 2302-6405, E-ISSN 2714-9765 
penggunaan kearifan lokal dalam pembelajaran ini bermanfaat untuk memperlancar proses interaksi antara pengajar dan pembelajar. Hal ini bahwa dengan menggunakan media interaktif berbasis kearifan lokal akan menciptakan kondisi yang menyenangkan, mengingat belajar siswa lebih banyak dipenuhi oleh rasa ketertarikan siswa dalam belajar sehingga dapat meningkatkan hasil belajar. Dengan demikian bahwa penerapan media dapat memotivasi dan membantu pembelajaran untuk belajar secara optimal.

Masalah dasar yang dikeluhkan oleh guru di Sekolah Menengah Atas pada pembelajaran Bahasa Indonesia adalah rendahnya kemampuan menyimak siswa, terutama pada pembelajaran menyimak cerita rakyat. Hal ini didasari oleh rendahnya kemampuan siswa dalam mengungkapkan apa yang sudah didengar dikarenakan daya menyimak siswa rendah, tidak adanya keseriusan dalam menerima pembelajaran, dan siswa yang kurang aktif dalam kegiatan pembelajaran. Sesuai dengan standar kompetensi memahami siaran atau cerita yang disampaikan secaralangsung/tidak langsung dan kompetensi dasar mengidentifikasi unsur sastra (intrinsik dan ekstrinsik) suatu cerita yang disampaikan secara langsung/melalui rekaman.

Ungkapan di atas bahwa banyak siswa yang kurang mampu dalam menyimak cerita rakyat, hal ini juga dialami siswa Sekolah Menengah Atas. Khususnya di Sekolah
Menengah Atas Negeri 1 Segedong. Dapat dibuktikan dengan nilai ratarata yang diperoleh oleh siswa yakni 64,02. Nilai tersebut tidak mencapai KKM yang telah ditetapkan sekolah dengan nilai KKM 70. Seperti halnya ketika guru membacakan sebuah cerita rakyat kepada siswa dan siswa disuruhmendengarkan cerita tersebut. Setelah guru selesai membacakan cerita rakyat lalu guru menanyakan kepada siswa pertanyaan-pertanyaan sesuai dengan indikator pembelajaran, namun hasilnya adalah lebih banyak siswa yang bingung dan diam untuk menjawab dan dari itu juga siswa meminta guru untuk mengulangi membacakan cerita rakyat tersebut.

Faktor penyebab rendahnya kemampuan menyimak cerita rakyat adalah faktor dari siswa sendiri dan faktor dari guru. Faktor penyebab dari siswa adalah siswa cenderung kurang dapat menyimak dengan serius, siswa kurang berkonsentrasi, dan kurang aktif dalam menerima pembelajaran, hal ini dikarenakan kurang menariknya suatu cerita atau yang membacakan cerita. Agar siswa lebih semangat dan tertarik serta aktif dalam menyimak, maka akan dikembangkan media pembelajaran interaktif dengan menampilkan sebuah rekaman atau video cerita rakyat yang berbasis kearifan lokal daerah setempat siswa. Sedangkan faktor penyebab rendahnya kemampuan menemukan hal-hal yang menarik tentang tokoh cerita rakyat adalah kurangnya kreativitas guru dalam menggunakan alat/bahan yang 
dapat membantu siswa dalam pembelajaran.

\section{METODE}

Penelitian ini dilaksanakan di kelas X SMAN 1 Segedong yang berjumlah 19, laki-laki 3 siswa dan perempuan 16 siswa. Desain penelitian menggunakan prosedur penelitian dan pengembangan (Research and Development). Sugiyono (2016) Metode penelitian dan pengembangan atau dalam bahasa inggrisnya Research and Development adalah metode penelitian yang digunakan untuk menghasilkan produk tertentu dan menguji keefektifan produk tersebut.

Menurut Sugiyono (2016) "Penelitian pengembangan mempunyai empat tingkat kesulitan yaitu: meneliti tanpa menguji (tidak membuat dan tidak menguji produk), menguji tanpa meneliti (menguji validitas produk yang telah ada), meneliti dan menguji dalam upaya mengembangkan produk yang telah ada dan meneliti dan menguji dalam menciptakan produk baru".

Terdapat banyak model desain pembelajaran (Botturi, 2003) yang dapat digunakan untuk mengembangkan perangkat pembelajaran, salah satunya adalah model Hannafin dan Peck.

Model Hannafin dan Peck menurut (Tegeh, dkk, 2014) merupakan model yang sederhana, dimana model ini berfokus pada pemecahan masalah kendala kualitas dan kompleksitas pengembangan yang terdiri dari tiga tahapan yakni; 1) penilaian kebutuhan; 2) tahap desain; dan 3) pengembangan dan evaluasi, dimana ketiga tahapan terhubung pada kegiatan "evaluasi dan revisi" yang merupakan tahap yang sangat penting dalam penyempurnaan dari perangkat pembelajaran pada ketiga tahapan inti.

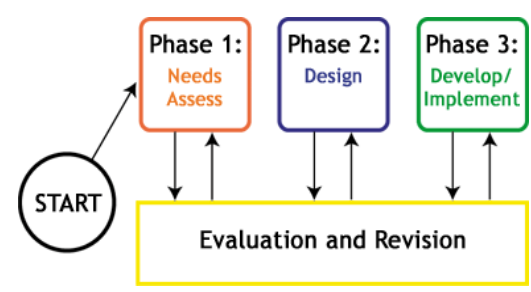

Gambar 1. Tahapan Model Pengembangan Hannafin dan Peck

Bentuk instrument tes adalah tes hasil belajar siswa. Tes ini bertujuan untuk mengukur pemahaman siswa tentang materi yang diberikan melalui media interaktif berbasis kearifan lokal.

Validasi kelayakan media dan materi dilakukan oleh para ahli untuk melihat uji kelayakan media interaktif berbasis kearifan lokal yang akan digunakan dalam pembelajaran.

Penyebaran

kuisioner dilakukan kepada para siswa untuk melihat analisis kebutuhan siswa dalam pembelajaran. Wawancara dilakukan secara tidak formal terstruktur guna memperoleh informasi pendukung dari kuisioner analisis kebutuhan yang disebarkan kepada siswa.

Prosedur penelitian dan pengembangan dalam penelitian ini 
mengikuti penelitian dan pengembangan rancangan Hanafin and Peck dengan tahapan-tahapan penilaian kebutuhan, desain dan pengembangan dan evaluasi.

\section{HASIL DAN PEMBAHASAN}

Kegiatan penelitian diawali dengan pemberian pre test kepada siswa untuk mengetahui kemampuan awal siswa terkait materi menyimak cerita rakyat. Berikut disajikan hasil pre tes siswa pada materi menyimak cerita rakyat pada tabel 1 .

Tabel 1. Hasil Pre Test Siswa

\begin{tabular}{ccc}
\hline $\begin{array}{c}\text { Jumlah } \\
\text { Siswa }\end{array}$ & $\begin{array}{c}\text { Rata- } \\
\text { Rata Pre } \\
\text { Test }\end{array}$ & Kriteria \\
\hline 19 & $68,16 \quad$ Cukup \\
& & \\
\hline
\end{tabular}

Berdasarkan tabel 1 dari 19 orang siswa yang diberikan pre test, diperoleh rata-rata hasil pre test sebesar 68,16 dengan kategori cukup.Berdasarkan hasil pre test, selanjutnya dilakukan pemberian angket kepada siswa yang bertujuan untuk menganalisis kebutuhan siswa terkait media pembelajaran yang sesuai untuk digunakan dalam pembelajaran khususnya pada materi menyimak cerita rakyat. Dari hasil pemberian angket diketahui analisis kebutuhan siswa dapat dilihat pada Tabel 2.
Tabel 2. Analisis Kebutuhan Siswa

\begin{tabular}{|c|c|c|}
\hline $\begin{array}{c}\text { Jumlah } \\
\text { Siswa }\end{array}$ & $\begin{array}{c}\text { Item } \\
\text { Kebutuhan }\end{array}$ & $\begin{array}{l}\text { Persentase } \\
\text { Kebutuhan }\end{array}$ \\
\hline \multirow{3}{*}{19} & $\begin{array}{c}\text { Media } \\
\text { Interaktif }\end{array}$ & $65 \%$ \\
\hline & $\begin{array}{l}\text { Media } \\
\text { Audio } \\
\text { Visual }\end{array}$ & $25 \%$ \\
\hline & $\begin{array}{l}\text { Media } \\
\text { Audio }\end{array}$ & $10 \%$ \\
\hline
\end{tabular}

Berdasarkan tabel 2 di atas, diperoleh bahwa analisis kebutuhan siswa akan ketersediaan media pembelajaran berupa media interaktif sebesar $65 \%$, media audio visual sebesar $25 \%$ dan media audio sebesar $10 \%$. Melihat dari perolehan persentase tersebut, maka dapat ditarik kesimpulan bahwa analisis kebutuhan siswa adalah tersedianya media pembelajaran berupa media interaktif yangdapat digunakan oleh guru dalam menyampaikan materi menyimak cerita rakyat. Hal ini sejalan dengan Praheto dkk (2017) dengan simpulan hasil penelitian bahwa media interaktif dapat membantu siswa dalam menguasai empat aspek keterampilan dalam belajar bahasa Indonesia yakni keterampilan menyimak, berbicara, membaca dan menulis.

Berdasarkan analisis kebutuhan yang diperoleh, peneliti bermaksud melakukan perancangan media pembelajaran berupa media interaktif berbasis kearifan lokal pada materi menyimak cerita rakyat. Hal ini dilakukan dengan tujuan agar media 
interaktif yang akan digunakan dalam pembelajaran dapat meningkatkan hasil belajar siswa pada materi menyimak cerita rakyat.

Sebelum diimplementasikan media dilakukan validasi kelayakan media oleh para ahli dalam hal ini adalah dua orang dosen dari bidang keilmuan Teknologi Informasi dan Komputer. Berikut disajikan hasil validasi kelayakan media pada tabel 3 .

Tabel 3. Validasi Kelayakan Media

\begin{tabular}{|c|c|c|c|c|}
\hline \multirow{2}{*}{ Kriteria } & \multicolumn{2}{|c|}{ Nilai } & \multicolumn{2}{|c|}{ Validasi } \\
\hline & Ahli 1 & Ahli 2 & Ahli 1 & Ahli 2 \\
\hline $\begin{array}{l}\text { Kombinasi } \\
\text { warna } \\
\text { menarik. }\end{array}$ & $64 \%$ & $55 \%$ & Layak & Cukup \\
\hline $\begin{array}{l}\text { Warna tidak } \\
\text { mengganggu } \\
\text { visualisasi } \\
\text { media. }\end{array}$ & $58 \%$ & $66 \%$ & Cukup & Layak \\
\hline $\begin{array}{l}\text { Menggunaka } \\
\text { n Bahasa } \\
\text { Indonesia } \\
\text { yang sesuai } \\
\text { dengan ejaan } \\
\text { yang } \\
\text { disempurnaka } \\
\text { n (EYD). }\end{array}$ & $82 \%$ & $84 \%$ & $\begin{array}{r}\text { Sangat } \\
\text { Layak }\end{array}$ & $\begin{array}{l}\text { Sangat } \\
\text { Layak }\end{array}$ \\
\hline $\begin{array}{l}\text { Bahasa yang } \\
\text { digunakan } \\
\text { mudah } \\
\text { dipahami. }\end{array}$ & $77 \%$ & $72 \%$ & Layak & Layak \\
\hline $\begin{array}{l}\text { Kata yang } \\
\text { digunakan } \\
\text { konsisten. }\end{array}$ & $74 \%$ & $74 \%$ & Layak & Layak \\
\hline $\begin{array}{l}\text { Tata letak } \\
\text { tiap halaman } \\
\text { seimbang. }\end{array}$ & $73 \%$ & $69 \%$ & Layak & Layak \\
\hline $\begin{array}{l}\text { Tipe huruf } \\
\text { yang } \\
\text { digunakan } \\
\text { terlihat jelas } \\
\text { dan dapat } \\
\text { terbaca. }\end{array}$ & $80 \%$ & $78 \%$ & Layak & Layak \\
\hline
\end{tabular}

Berdasarkan hasil validasi kelayakan pada tabel 3. Terlihat bahwa kedua ahli memberikan penilaian validasi pada kriteria cukup, layak serta sangat layak. Dengan demikian berdasarkan penilaian tersebut media interaktif yang dikembangkan dikategorikan layak untuk dapat diimplementasikan kepada siswa.

Selain validasi media, juga dilakukan validasi kelayakan materi oleh para ahli dalam hal ini adalah dua orang dosen dari bidang keilmuan pendidikan Bahasa Indonesia. Berikut disajikan hasil validasi kelayakan materi pada tabel 4 .

Tabel 4. Validasi Kelayakan Materi

\begin{tabular}{lllll}
\multicolumn{1}{c}{ Kriteria } & \multicolumn{2}{c}{ Nilai } & \multicolumn{2}{c}{ Validasi } \\
\cline { 2 - 5 } & Ahli 1 & Ahli 2 & Ahli 1 & Ahli 2 \\
& & & & \\
\hline $\begin{array}{l}\text { Media dapat } \\
\text { digunakan } \\
\text { pada individu } \\
\text { maupun }\end{array}$ & $66 \%$ & $65 \%$ & Cukup & Cukup \\
$\begin{array}{l}\text { kelompok } \\
\text { belajar. }\end{array}$ & & & & \\
\hline $\begin{array}{l}\text { Tujuan } \\
\text { pembelajaran } \\
\text { sesuai dengan } \\
\text { kurikulum. }\end{array}$ & $68 \%$ & $66 \%$ & Cukup & Cukup \\
\hline $\begin{array}{l}\text { Memuat } \\
\text { indikator } \\
\text { yang sesuai } \\
\text { dengan tujuan } \\
\text { pembelajaran. }\end{array}$ & $81 \%$ & $83 \%$ & Layak & Layak \\
\hline $\begin{array}{l}\text { Isi media } \\
\text { sesuai dengan } \\
\text { materi yang } \\
\text { diajarkan. }\end{array}$ & & & & \\
\hline
\end{tabular}

Berdasarkan hasil validasi kelayakan materi pada tabel 4. Terlihat bahwa kedua ahli memberikan 
penilaian validasi pada kriteria cukup serta layak. Dengan demikian berdasarkan penilaian tersebut media interaktif yang dikembangkan dikategorikan layak untuk dapat diberikan kepada siswa.

Kegiatan penelitian dilanjutkan dengan pemberian post test kepada siswa untuk mengetahui sejauh mana kemampuan siswa terkait materi yang telah disampaikan menggunakan media interaktif berbasis kearifan lokal. Berikut disajikan hasil pre tes siswa pada materi menyimak cerita rakyat pada tabel 1 .

Tabel 5. Hasil Post Test Siswa

\begin{tabular}{ccc}
\hline JumlahSiswa & $\begin{array}{c}\text { Rata- } \\
\text { Rata Pre } \\
\text { Test }\end{array}$ & Kriteria \\
\hline 19 & 80,31 & Baiksekali \\
\hline
\end{tabular}

Berdasarkan tabel 5 dari 19 orang siswa yang diberikan post test, diperoleh rata-rata hasil post test sebesar 80,31 dengan kategori baik sekali.

Berdasarkan hasil pre test serta post test yang telah diperoleh, dilakukan pengujian untuk melihat peningkatan hasil belajar siswa setelah menggunakan media interaktif berbasis kearifan lokal. Berikut disajikan hasil perhitungan peningkatan hasil belajar siswa menggunakan effect size pada tabel 6 .

Tabel 6. Hasil Perhitungan Effect Size

$\begin{array}{ccc}\text { JumlahSiswa } & \begin{array}{c}\text { Effect } \\ \text { Size }\end{array} & \text { Kriteria }\end{array}$

$19 \quad 0,86 \quad$ Besar

Berdasarkan tabel 6 diperoleh hasil perhitungan effect size sebesar 0,86 dengan kategori "besar". Hasil uji menunjukkan bahwa pembelajaran menggunakan media interaktif berbasis kearifan lokal yang telah dilakukan berpengaruh besar dalam meningkatkan hasil belajar siswa. Temuan ini relevan dengan penelitian (Darmawan, 2020) dengan hasil penelitian diperoleh hasil belajar setelah digunakannya media pembelajaran interaktif sebesar 86,67. Hasil penelitianjuga relevan dengan hasil penelitian Mureiningsih (2014) dengan hasil penelitian menunjukkan terdapat peningkatan hasil belajar menggunakan media interaktif, pada pertemuan pertama hasil belajar diperoleh 66,05 meningkat menjadi 72,36 pada pertemuan kedua dan meningkat lagi sebesar 81,08 pada pertemuan ketiga. Selain itu hasil penelitian Kurniawan dkk (2016) diperoleh bahwa terdapat peningkatan hasil belajar pada penggunaan media interaktif multimedia sebelum dan setalah pembelajaran, sebelum pembelajaran diperoleh nilai 52,00 dan setelah pembelajaran sebesar 82,67.

\section{SIMPULAN}

Pengembangan media interaktif berbasis kearifan local ternyata setelah diterapkan mampu memberikan pengaruh dalam peningkatan hasil belajar siswa pada 
materi menyimak cerita rakyat. Peningkatan tersebut terlihat dari berhasilnya media interaktif berbasis kearifan local berperan dalam proses pembelajaran dan mengambil peran dalam peningkatan hasil belajar siswa. Hal ini terlihat dari meningkatnya rata-rata hasil belajar siswa dari tes awal sebesar 68,16 menjadi 80,31 pada tesakhir. Kemudian berdasarkan pengujian menggunakan effect size diperoleh nilai 0,86 dengan kriteria besar. Hal ini dapat disimpulkan bahwa media interaktif berbasis kearifan local berpengaruh besar terhadap peningkatan hasil belajar siswa.

\section{REFERENSI}

Botturi, L. (2003). Instructional Design and Learning Technology Standart: An Overview.IceF-Quardeni dell'Istituo, 9

Darmawan, H. (2020). Pengembangan Media Pembelajaran Interaktif dan Lembar Kerja Siswa Pada Materi Virus. Jurnal Pendidikan Biologi ,5(1), 28-36.

Ekawati, S., dkk. (2016). Pengaruh Kedisiplinan dan Aktivitas Belajar Terhadap Hasil Belajar Matematika Siswa. Pedagogy, 1(2), 119-130

Hijriyah, U. (2016). Menyimak Strategi dan Implikasinya dalam Kemahiran Berbahasa.

Lampung: IAIN Raden Intan Lampung.

Komariah, Y. (2018). Pengembangan Bahan Ajar Cerita Rakyat Kuningan Terintegrasi Nilai Karakter dalam Pembelajaran
Apresiasi Sastra di SMP. Deiksis; Jurnal Pendidikan Bahasa dan Sastra Indonesia, 1(1), 100-110.

Kurniawan, dkk. (2016). Pengembangan Multimedia Ular Tangga Model Hannafin and Peck Untuk Meningkatkan Hasil Belajar Mata Pelajaran IPA Pada Siswa Kelas VIII Semester Genap Di SMP Negeri 6 Singaraja Tahun Pelajaran 2015/2016. e-Journal Edutech Universitas Pendidikan Ganesha 5 (2).

Mureiningsih. (2014). Meningkatkan Hasil Belajar Siswa Melalui Media Pembelajaran Multtimedia Interaktif. Jurnal Madaniyah Edisi VII.

Musfiroh, Tadkiroatun (2010). Pengembangan Kecerdasan Majemuk. Jakarta: Universitas Terbuka

Praheto, dkk. (2017). Peran Multimedia Interaktif dalam Pembelajaran Keterampilan Berbahasa Indonesia Di PGSD. The 1 st Education and Language International Conference Proceedings. p. 173177.

Prihadi, B. (2014). Penerapan Langkah-Langkah Pembelajaran Dengan Pendekatan Saintifik dalam Kurikulum 2013. Bahan Seminar Tidak dipublikasikan. Pekalongan: In House training Implementasi Kurikulum 2013.

Sardiman. (2006). Interaksi dan Motivasi Belajar Mengajar. Jakarta: Raja Grafindo Persada.

Sugiyono. (2016). Metode Penelitian Kuatitatif, Kualitatif, dan $R \& D$. Bandung: Alfabeta.

Tegeh, dkk (2014). Model Penelitian dan Pengembangan. Bali: Graha Ilmu. 